\title{
Editorial
}

\section{THE VALUE OF VISIBILITY AND THE VALUE OF TRUTH}

A few months ago, in the middle of a war which the United States had no business starting, and in which countless Latino and Latina soldiers are being killed or are coming home maimed; in the middle of unwarranted and inhumane raids of undocumented workers in which Latino and Latina workers are being detained in secret locations far from their children and spouses, left behind with no warning; the Public Broadcasting Company made it known that they would be releasing Ken Burns' 14 hour long documentary on World War II. Six years in the making, and titled "THE WAR," the series was to air in September - without any mention of the participation and multiple contributions, heroism, and sacrifices of the hundreds of thousands of Mexican Americans, Puerto Ricans, and other Latinos in both the battlefields and on the home front. Today, as a result of the active protest and letter-writing campaign organized by Professor Maggie Rivas Rodríguez and her colleagues through the Defend The Honor campaign (http://www.defendthehonor.org), and supported by Latino/a veterans, organizations, scholars and politicians throughout the country, PBS and Ken Burns have agreed to incorporate the Latino/a experience. The terms of that inclusion are currently under negotiation.

When I first heard of the omission, I thought about the three Latino soldiers who were among the first to die for their country - adopted or otherwise - in the current war in Iraq. I remember thinking how much these kinds of media distortions and omissions contribute to the fact that Latinos in the US are viewed solely as "criminals," as border-crossing law-breakers, as only taking from - and never giving back to - this country. After all, those are the main images of Latino/as that the media relentlessly presents to the "American people" - what mainstream USA sees again and again and what this society has been taught.

In addition to the blatant show of historical irresponsibility toward the full truth of US history originally shown by Ken Burns and PBS alike, I was also particularly disturbed by Mr. Burns' response to the wave of letters he received from Latino organizations and individuals, and particularly by his claim that "We were looking for the universal, human experience of battle, what was it like to be in that war, and not try to cover every group."

Surely Mr. Burns is aware that the essence of "universal human experience" can only be captured through the details of individuals' lives and contributions. Surely he knows that the emphasis on "universal" abstractions necessarily must distort and undermine the complexity of

䏠. Latino Studies 2007, 5, (153-156) (C) 2007 Palgrave Macmillan Ltd 1476-3435/07 \$30.00 www.palgrave-journals.com/lst 
"universal human experience." After all, in every war - including World War II - it is individual men and women who make the decision to participate in their country's battles; it is individual men and women who must lose their lives for their country; it is individuals who make the sacrifice on the front lines, and who must confront, on a daily basis, the risk of dying, of being maimed, of being mutilated on the battlefield and returning "home" as invalids.

This was certainly the case of the hundreds of thousands of Mexican Americans, Puerto Ricans, and other Latinos who became part of the US armed forces in WWII - and indeed of every war in which the United States as a nation has been engaged throughout its history - including the current war in Iraq. This is certainly the case of all the Latinos who left their homes in the United States to participate in the international struggle against the threat of fascism in Europe - in spite of their placement in segregated battalions, in spite of the multiple humiliations and racism that they, like their African American counterparts, were forced to confront and contend with on a daily basis, both at home and abroad. In addition, thousands of Latin American citizens, residents, immigrants were recruited as Braceros to work in the fields and factories, hence also contributing to the war effort on the home front. Moreover, the hundreds of thousands of individual Latino family members left behind by these courageous and patriotic Latino citizens also endured many hardships and sacrificed themselves on a daily basis to support their husbands, wives, uncles, aunts, sons, daughters, cousins and friends in the war effort in both the European battle fields and on the domestic front. Like all the countless Latinos who joined the US armed forces during WWII, they too deserve to be recognized in their country - the United States - as having made significant sacrifices and multiple contributions, like all Americans, in the "universal human experience of battle."

It is indeed surprising that PBS has had to be so forcefully reminded that Latinos' insistence on their inclusion in this documentary should not be seen either as sectarian or solely as a reflection of Latinos' response to their ongoing invisibility in the media and history text books - nor should it be understood as being for the benefit of Latinos alone. Quite the contrary: such inclusion serves to bring all people in the USA together. After all, a key aspect of the mission of public television entails serving the national community as a whole, through creating greater self-awareness and self-knowledge in the national society.

Today, as in the past, US society's response to the presence of Latino residents and citizens - most clearly visible in the daily raids and assaults against Latino immigrant workers and families - belies the historical and ongoing contributions that Latinos, regardless of their political status, have historically made and continue to make towards the well-being of everyone in this society - and these contributions include defending and dying for this country. This response is, to a large extent, an obvious consequence of the perennial ignorance in the society, 
fueled by the ongoing exclusion of Latinos' historical participation and multiple contributions in the accounts of the nation's history, in documentaries such as the forthcoming one Ken Burns produced.

From this point of view, the success of the Defend the Honor campaign in its effort to reverse this trend by getting Ken Burns and PBS to agree to incorporate Latino contributions into this six-part series, will contribute to breaking this vicious circle. Indeed, the wave of protest by Latino organizations and individuals across the country to yet another factually misleading account of US participation in WWII can primarily be understood to be another effort at demanding that the history of this nation be told in ways which will enable all of us to become more knowledgeable of the truth of the country's multicultural history; to better understand the roots of this society's continued inability to address the persistent racializing exclusion of significant numbers of people of color - both Latinos and others - (including Native Americans, African Americans, Asian Americans) from this society's past. This will in turn allow the true meaning of Americans' "universal, human experience of battle" to indeed be captured - for all Americans.

Moreover, it will also help all Americans to address with greater precision, the existing social, racial, and political problems which Latinos are constantly required to address in multiple public spaces on a daily basis.

The articles in this issue exemplify some of these problems and their consequences in Latino/as' daily lives. Ben Bailey, for example, discusses the impact of the society's black/white divide on the ways racial identity shifts among second-generation Dominicans raised in this country, and argues for a reconsideration of theories focusing on the trajectories of immigrant acculturation in US society, in order to incorporate the Latino/a experience. Lisa Marie Cacho examines the ways in which the lives and deaths of young Latino men are not valued in this society, largely as a result of the emphasis on social deviancy associated with the term "Latino/a" in the media. Nicole M. GuidottiHernández focuses on the fact that the globalized juvenile Latino/a television market has become increasingly multicultural and pro-bilingual despite the fact that most States in the US have slashed the budgets of or altogether eliminated the presence of bilingual education. Through her analysis of "Dora the Explorer," she shows that nation, citizenship, and identity are a contested terrain and that the successes of juvenile television programs are best understood in terms of the commercialization and marketing of Latinidades, with real-world implications for US Latino/as and Latin Americans. Finally, Patricia Fortuny Loret de Mola and Philip J. Williams focus on the ways in which religious and civic institutions operate in a multiethnic migrant farmworker community, and argue that while religious organizations are an important source of social capital, they tend to reinforce the segregation of groups by both ethnicity and region. Instead, their study of Immokalee workers suggests that secular organizations may be more effective in addressing the 
heterogeneity and mobility of migrant populations, and in generating "political capital" that seeks to affect political and social change.

Our Reflexiones Pedagógicas article focuses on one of the most pressing issues that young second-generation Latino/as currently confront as they struggle for their right to education in this country. Based in California, the authors, Maria Lucia Chavez, Paz M. Oliverez and Mayra Soriano, detail the struggle to implement $\mathrm{AB} 540$, which would allow thousands of Latino/a students raised in this country, to have access to higher education. Finally, in our Vivencias section, Mino Treviño, a Chicano marine during the Gulf War, describes the painful search by returning war veterans, for "peace of mind"...

In this issue, we say a sad goodbye to our invaluable Managing Editor, Karen Benita Reyes - without whose help this Journal would not have arrived at its present state of development. I want to take this opportunity to thank Karen on behalf of the journal's Associate Editors, the International Advisory Board, and our authors, for her commitment, dedication, and constant support for the work of the Journal, for the field of Latino Studies, and for me.

Saludos!

Suzanne Oboler University of Illinois at Chicago, Chicago

Latino Studies (2007) 5, 153-156. doi:10.1057/palgrave.lst.8600258 